\title{
Integrating Different Databases to Offer a Geological Perspective of Coastal Management: A Review Case from the Northern Tuscany Littoral Cell (Italy)
}

\author{
Giovanni Sarti *(D), Duccio Bertoni (D) and Monica Bini (D) \\ Dipartimento di Scienze della Terra, University of Pisa, Via Santa Maria 53, 56126 Pisa, Italy; \\ duccio.bertoni@unipi.it (D.B.); monica.bini@unipi.it (M.B.) \\ * Correspondence: giovanni.sarti@unipi.it; Tel.: +39-050-2215700
}

check for updates

Citation: Sarti, G.; Bertoni, D.; Bini, M. Integrating Different Databases to Offer a Geological Perspective of Coastal Management: A Review Case from the Northern Tuscany Littoral Cell (Italy). J. Mar. Sci. Eng. 2022, 10, 353. https://doi.org/10.3390/ jmse10030353

Academic Editor: Dimitris Sakellariou

Received: 9 February 2022 Accepted: 25 February 2022 Published: 2 March 2022

Publisher's Note: MDPI stays neutral with regard to jurisdictional claims in published maps and institutional affiliations.

Copyright: (c) 2022 by the authors. Licensee MDPI, Basel, Switzerland. This article is an open access article distributed under the terms and conditions of the Creative Commons Attribution (CC BY) license (https:// creativecommons.org/licenses/by/ $4.0 /)$.

\begin{abstract}
A multidisciplinary approach to coastal process research has been increasingly encouraged in the last decade, and it is now widely accepted for a thorough, in-depth analysis of any issue related to such an environment. In this study, we emphasized the need for the integration of different time-scales, not just disciplines. Many geological datasets provided by several sources contribute to the knowledge of coastal processes. We retrieved the available datasets about morphodynamic, geomorphological, and geological aspects of the northern Tuscany (Italy) littoral cell, and we merged all of them with QGIS (Quantum Geographic Information System) applications to provide an assessment of the current situation starting from a geological perspective. Data processing resulted in maps and stratigraphic sections that confirmed that sediment supply is the main factor driving the evolution of the littoral cell. Such a perspective is also useful for the development of reliable coastal evolution future scenarios, not just for a better definition of the present situation. As these datasets are now available for many sectors of coast around the world, this approach may be easily replicated elsewhere to improve coastal management policy making.
\end{abstract}

Keywords: stratigraphic correlation; facies analysis; sequence stratigraphy; coastal morphodynamics; database; littoral cell; sediment distribution; management; Tuscany

\section{Introduction}

Coastal areas worldwide are densely populated. In Europe, more than $40 \%$ of people live within $10 \mathrm{~km}$ from the coastline; on a global scale, $44 \%$ of the population lives within $150 \mathrm{~km}$, and the majority of megacities are built along the coast [1,2]. In coastal areas, the economic concentration of stakeholders, rising number of inhabitants, and growing urbanization are strictly correlated and progressively increasing [3]. For instance, the U.S. coastal population grew by $84 \%$ in the interval between 1960 and 2008 [4]. A projection of inhabitants living within $100 \mathrm{~km}$ from the shoreline by 2035 indicated a worldwide increase, except for Europe because of zero or negative population growth rates [5]. This process has been leading to strong changes in the natural environment through uncontrolled concreting, widespread reclamations, building of a huge number of coastal defense structures, destruction of coastal dune ridges, pollution, and so forth. Moreover, both natural and human-induced changes in the coastline position over time have undermined socio-economic stability and economic growth [6]; they are now perceived as a danger to institutions and citizens. Numerous studies have been carried out about the comprehension of coastal morphodynamic mechanisms, spanning from natural settings to sites where human-induced climate change variations have strongly affected the environment [7-14]. These studies are often focused on a present-day time-scale (tens of years), though they do not take into account that (i) the current situation is also a result of the inherited history from the past centuries, and (ii) the last century is itself the result of geological sedimentary cycles that occurred thousands and tens of thousands of years ago. While the natural 
processes (e.g., climatic phases, sedimentary supplies, local tectonics, and sea level eustatic changes) still have imposed variations to the coastline $[15,16]$, the overlapping of human factors [17-22] has become increasingly important, becoming the most important drivers nowadays (e.g., greenhouse effect, anthropic subsidence, decrease of river sedimentary supply due to dam construction, modification of littoral drift due to the presence of coastal defense). We believe that the integration of these different time-scales in a single and coherent framework (i) prompts a better knowledge of the present-day systems and (ii) represents the basis to apply increasingly reliable future scenarios. The aim of this study is to analyze the space-time evolution of the northern Tuscany littoral cell (Italy) at different time-scales from a geological perspective up to the current situation through the analysis and integration of the available datasets.

\section{Physical Setting}

\subsection{Geological and Morphological Setting}

The northern Tuscany littoral cell is oriented along a north-south direction, except for the northern sector, which presents a NW-SE bend. The northern limit is represented by the Punta Bianca headland, whereas the Livornesi Mounts border the cell to the south (Figure 1). The littoral cell is located within two extensional basins, and for most of its extension, it overlies the Viareggio Basin (from the Livornesi Mounts to approximately the village of Marina di Massa).

The northernmost stretch of the littoral cell is located in the southern portion of the Magra Basin, corresponding to the area where the homonymous river flows. Both basins formed because of the extensional regime endured during the opening of the Tyrrhenian Sea back-arc basin [23-25] and developed parallel to the direction of the Apennines chain (NW-SE). The Viareggio Basin is a half-graben bounded by a listric fault that was active during the middle-to-late Pliocene. The activation of the half-graben dates to the upper Miocene. According to [26], the geological boundaries are defined by the Pisan Mounts (north-east), the Livornesi Mounts (south-east), and the Secche della Meloria (south-west); the north-western limit is yet to be unequivocally identified, but a study by [27] indicated the area of Marina di Massa as the possible northern edge. Presently, the depocenter of the basin (up to $2500 \mathrm{~m}$ deep) is located in the area of the Arno River mouth. The top hundred meters of the coastal plain subsurface consist of a cyclic alternation of continental and nearshore deposits related to glacial-interglacial cycles, which have ultimately been explained as a series of transgressive-regressive sequences [28-30]. On the other hand, the Magra Basin is a graben defined by two structures on the western and eastern sides: respectively, the Punta Bianca horst and the Apuan Alps [26]. Its formation dates to the Pliocene and is related to high-angle normal faults, located and still visible in the area of the Punta Bianca headland [26,31,32]. The two extensional basins are characterized by natural subsidence as a result of local tectonics and sediment compaction $[24,33]$. From a geomorphological point of view (Figure 2), the northern Tuscany littoral cell is characterized by a wide strandplain area mainly fed by the Magra and Arno rivers and, subordinately, by the Serchio River. Moving in a landward direction, five main morphological areas can be recognized. They are constituted by (a) beach, (b) beach ridge dune alignment, (c) coastal plain, (d) lowland marsh or lake, and (e) alluvial fan.

The beaches (a) are mostly sandy, except for the northern area where the shore is also characterized by gravel. The main characteristic of this area is the alternation of natural and highly-anthropized sectors. A large beach ridge system (b) developed landward of the beach [34]; it is constituted by the juxtaposition of several foredunes. These natural beach ridges have been obliterated by human activities over time, except for the MigliarinoSan Rossore-Massaciuccoli Regional Park. This reserve area is located between Tirrenia and the Massaciuccoli Lake (Figure 2). The area is characterized by exceptional erosion processes, especially at the Arno River mouth [35]. Landward, the beach ridge system gradually converts to a wide coastal plain area (c). The width of the coastal plain is larger in the area surrounding the Arno River; it increasingly narrows north of the Port of 
Viareggio. A wide lowland marsh area (d) marked by the Massaciuccoli Lake developed south-east of Viareggio (Figure 2). Other marsh areas that formed similarly (e.g., Lago di Porta and the Arno River mouth) have been naturally or artificially silted up during the last centuries [36-39]. Coalescent alluvial fan lobes (e) are fed by the adjacent Apennines outcrop in the northernmost sector of the study area between Camaiore and the Magra River landward of the coastal plain, which is very narrow here (Figure 2). They are currently incised and terraced. The driving factor of their formation has been related to climatic change (i.e., the last glacial phase) and to the local uplift affecting the Apennines [40,41].

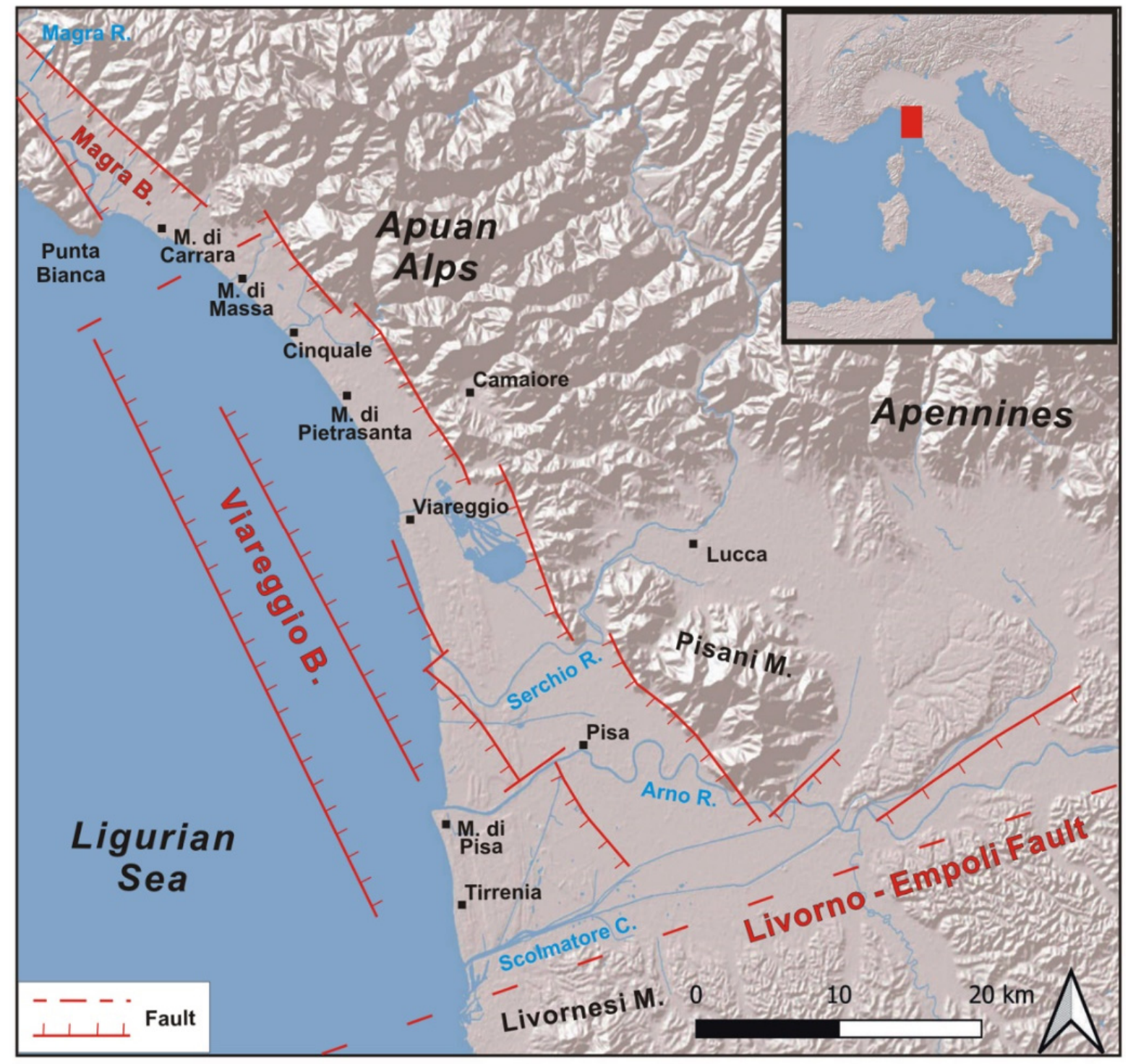

Figure 1. Map of the study area (northern Tuscany, Italy). Red lines correspond to the most significant geological features, such as faults. Basemap: ESRI Shaded Relief, available on QGIS QuickMap Services. Redrawn after [26]. 


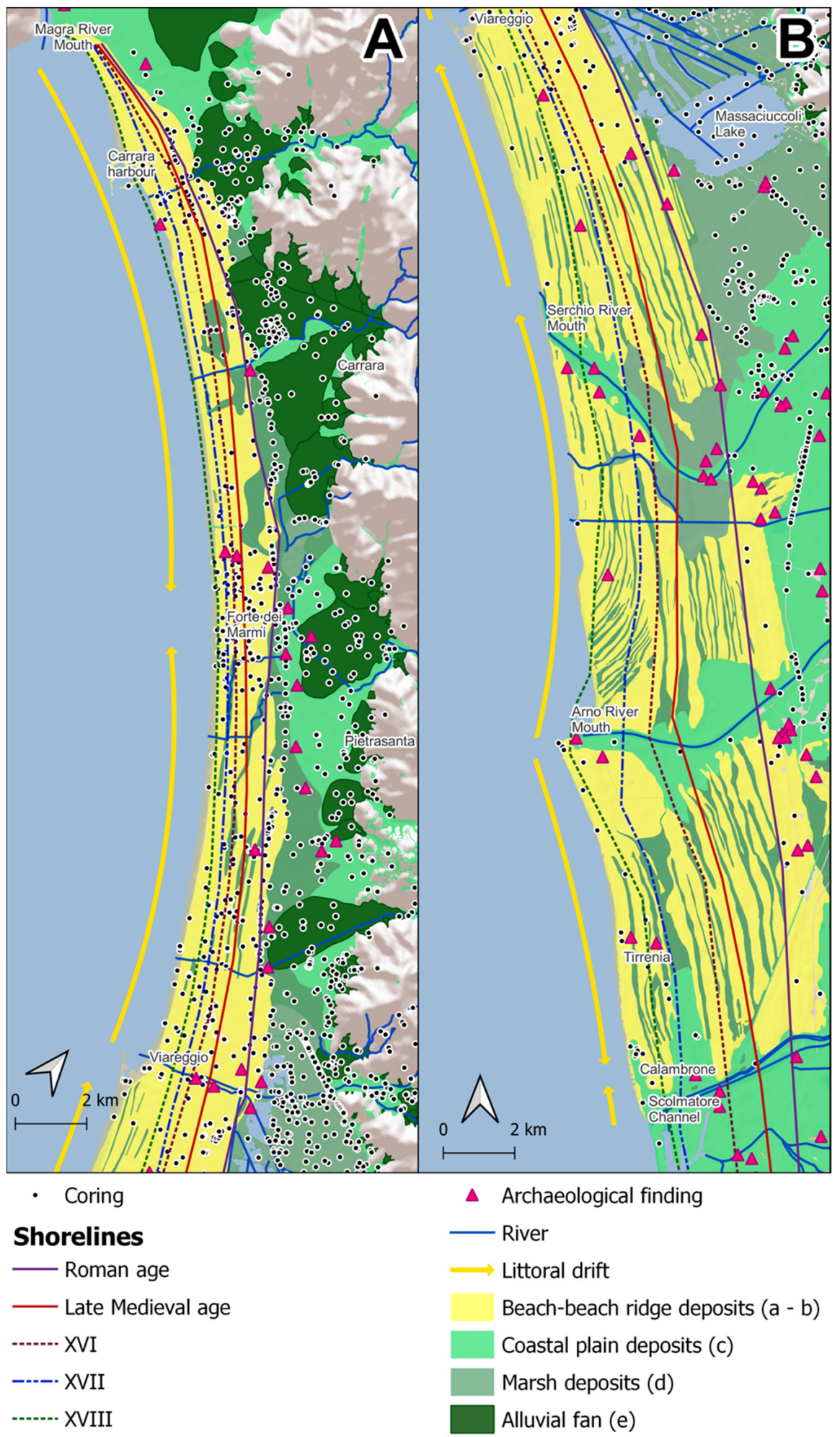

Figure 2. Geomorphological map of the study area showing the shoreline evolution since the Roman age. (A) Zoom-in of the sector between the Magra River mouth and the Port of Viareggio; (B) zoom-in of the sector between the Port of Viareggio and the Scolmatore Channel mouth.

\subsection{Morphodynamic Setting}

The present morphodynamic conditions of the northern Tuscany littoral cell have strongly been affected by the development of human activities since 1850. After centuries of consistent accretion along the shore, the last century has been characterized by profound 
modification in the balance between input and output, which ultimately has led to erosion effects at many sites along the cell [42]. Such variation was mainly determined by increasing human pressure on coastal settlements, both longshore (e.g., intense urbanization and the proliferation of hard structures) and in the river basin (e.g., riverbed dredging, dam construction, and river mouth armoring); all these factors have contributed to decreasing the sediment input of any local streams to the sea, which has translated to an extensive coastal retreat. However, waterworks along river courses have also been responsible for coastal progradation; the offset of the Arno River mouth in 1606 is a well-known example of such a practice [43]. The decision to rotate the mouth from SW to WNW was made to avoid exceptional floods inland whenever river overflows occurred at the same time as southwesterly sea storms. The river discharge increased massively after the intervention. Sediment accumulated longshore, resulting in a huge accretion of the delta lobes, which continued up to midway through the 19th century. Presently, erosion processes are still active at different sites along the littoral cell [42,44,45]. The most intense effects were documented in the northernmost sector between the Magra River mouth and Cinquale and at the Arno River, either north or south of the mouth (Figure 2). Conversely, accretion areas were located at Marina di Pietrasanta, which is a convergence zone of the littoral drifts coming from the Magra River and the Arno River, and updrift of the Port of Viareggio, where sediment coming from the eroding beaches' downdrift tends to accumulate. Another convergence zone was reported in the southernmost sector of the littoral cell, approximately at Tirrenia (Figure 2); here, the drift coming from the Arno River meets that coming from the south, whose origin is not fully understood yet [42]. The evidence of drift directions is also supported by the compositional analysis of the sediments constituting the beach. The sand in the sector between the Magra River mouth and the convergence zone at Marina di Pietrasanta shows a mineralogical composition resemblance to the bedload supplied by the Magra River: quartz (40\%), feldspar and mica $(<40 \%)$, and carbonates $(20 \%)[46,47]$. To the south, the input from the Arno River prevails over any other stream in that sector of the coast: quartz ( $>50 \%)$, feldspar and mica $(>25 \%)$, and carbonates $(20 \%)[46,48]$. The mean grain size is also an indication of sediment provenance. Pebbles and gravel are characteristic of the natural bedload discharge of the Magra River. The northernmost sector of the cell up to Cinquale presents scattered gravel along the shore, which is also a remnant of some artificial replenishments made with coarse sediments over the years [49]. The grain size progressively decreases southwards, from coarse sand at Marina di Massa to fine sand at Marina di Pietrasanta. South of the convergence zone, the mean grain size is typically around fine-to-medium sand [50]. Neither gravel nor pebbles are present in this sector of the littoral cell, except for the artificial marble beaches at Marina di Pisa [51,52]. The sea weather climate along the northern Tuscany littoral cell has no major variations from north to south in terms of wave height. Waves less than $2 \mathrm{~m}$ high are most frequent in any year, while waves between 2 and $4 \mathrm{~m}$ high are less common, but not negligible [34]. Wave states over $4 \mathrm{~m}$ in wave height can be defined as high-energy events for this sector of the Ligurian Sea. They usually come from the SW direction, as well as fair-weather waves, and are mostly associated with the Libeccio wind (SW). However, wave direction is not uniform throughout the littoral cell, as the northern sector is not exposed to northwesterly events because of its geographical position. The coastline bends to an east-west direction at the boundary between the Tuscany and Liguria regions (Figures 1 and 2), and the mountains act as a barrier preventing northwesterly winds and waves from hitting that sector of the coast. Therefore, high-energy events coming from the NW occur only in the central and southern sectors of the littoral cell. The northern Tuscany littoral cell is a microtidal environment [44]. The spring tide is hardly over $0.3 \mathrm{~m}$; such a tidal range has minimal effects on any morphodynamic process along the coast. 


\section{Dataset}

\subsection{Subsurface Data}

Several datasets were retrieved from the Mappa Project [53] and the website Geoscopio Regione Toscana [54], and from the archives of the Provincia di Pisa and the Comune di Pisa [55]. They were collected and grouped together to form a subsurface database in a QGIS (Quantum Geographic Information System) environment. This database was used to reconstruct the subsurface stratigraphic architecture of the upper Pleistocene-Holocene sedimentary cycle. Within this database consisting of many boreholes and piezocone tests (more than 2500, accuracy of about $3 \mathrm{~m}$ in geolocation), we selected the more complete and detailed core stratigraphy where the prominent key stratigraphic surfaces could be identified. Cores available in the scientific literature [28-30,56-60] were also taken into consideration to construct the sections and also as a reference for facies interpretation. All these data were processed and interpreted to produce stratigraphic sections within the study area. The characteristics of the key stratigraphic surfaces related to the Holocene transgression depended on the pre-Holocene depositional setting and were grouped into two typologies: (a) marine transgression occurring through an unconformity over continental deposits and (b) marine transgression taking place on sedimentary continuity upon estuarine deposits. The former is characterized by the abrupt transition from continental deposits (barren reddish clay and sands or coarse conglomerate over consolidated levels) related to alluvial fans or interfluve areas above sea level to fossiliferous marine sands. In the latter, the marine transgression occurs at the top of estuarine valley-fill deposits. In this case, the transition can be sharp or gradual and is between fossiliferous silty-clayey deposits and sands.

\subsection{Chronological and Archeological Data}

In order to constrain the stratigraphic reconstructions in a chronological framework, all the available dates from previous works $[56,58,61]$ were considered. They mainly consisted of tens of radiocarbon dates performed both on organic matter levels and mollusks. For the purpose of this study, we selected the dates obtained within an average of about $10 \mathrm{~km}$ from the current position of the coastline in order to guarantee the consideration of all the data related to the maximum landward Holocene transgression. The published archeological data useful for constraining the age of the coastline position during a certain time [36-38,61-69] were collected and included in the geomorphological map (Figure 2).

\subsection{Morphological Data}

In order to reconstruct the coastline evolution, the available data were acquired from different geo-databases [42,70,71]. The historical evolution of the coastline position was based on the integration of the available geomorphological data related to the outcropping beach ridges [72-75] with archeological data [36,72,73]. These data were provided by different methodological approaches, such as remote sensing, aerial photo images, field surveys, and ancient maps (Table 1). In this study, a linear shapefile with the position of the shoreline was created for each analyzed period. The data were processed using QGIS v. 3.10 open-source software (Reference System Gauss Boaga, Roma Italy 1, EPSG 3003).

Table 1. Details about coastline data showing the year of acquisition, the ownership, some additional data, and the reference.

\begin{tabular}{cccc}
\hline Year & Ownership Organization & Data Type & Reference \\
\hline 1878 & IGM & Carthography & {$[70]$} \\
1907 & IGM & Carthography & {$[70]$} \\
1928 & IGM & Carthography & {$[70]$} \\
1938 & IGM & Airborne Images & {$[70]$} \\
1944 & RAF & Airborne Images & {$[70]$} \\
1954 & Tuscany Region & Airborne Images & {$[70]$} \\
1975 & Tuscany Region & Airborne Images & {$[70]$} \\
\hline
\end{tabular}


Table 1. Cont.

\begin{tabular}{cccc}
\hline Year & Ownership Organization & Data Type & Reference \\
\hline 1978 & Tuscany Region & Airborne Images & {$[70]$} \\
1986 & IGM & Airborne Images & {$[70]$} \\
1990 & IGM & Airborne Images & {$[70]$} \\
1996 & Tuscany Region & Airborne Images & {$[70]$} \\
2003 & Tuscany Region & Airborne Images & {$[70]$} \\
2004 & Province of Pisa & Airborne Images & {$[70]$} \\
2008 & Province of Pisa, University of Pisa & DGPS survey & {$[71]$} \\
2009 & Province of Pisa, University of Pisa & DGPS survey & {$[71]$} \\
2010 & Province of Pisa, University of Pisa & DGPS survey & {$[71]$} \\
2011 & Province of Pisa, University of Pisa & DGPS survey & {$[71]$} \\
2012 & Province of Pisa, University of Pisa & DGPS survey & {$[71]$} \\
2013 & Province of Pisa, University of Pisa & DGPS survey & {$[71]$} \\
2014 & Province of Pisa, University of Pisa & DGPS survey & {$[71]$} \\
2015 & Province of Pisa, University of Pisa & DGPS survey & {$[71]$} \\
Roman Age & CNR, University of Pisa & Geoarchaeological data & {$[36]$} \\
Late Medieval Age & CNR, University of Pisa & Geoarchaeological data & {$[36]$} \\
XVI & CNR, University of Pisa & Geoarchaeological data & {$[36]$} \\
XVII & CNR, University of Pisa & Geoarchaeological data & {$[36]$} \\
XVIII & CNR, University of Pisa & Geoarchaeological data & {$[36]$} \\
\hline
\end{tabular}

\section{Dataset Analysis}

\subsection{Holocene Evolution (Tens of Thousands of Years)}

Four cross-shore transects were drawn along the littoral cell (Figure 3). They were selected to show the changing depositional organization from north to south in areas where reliable boreholes were mostly available.

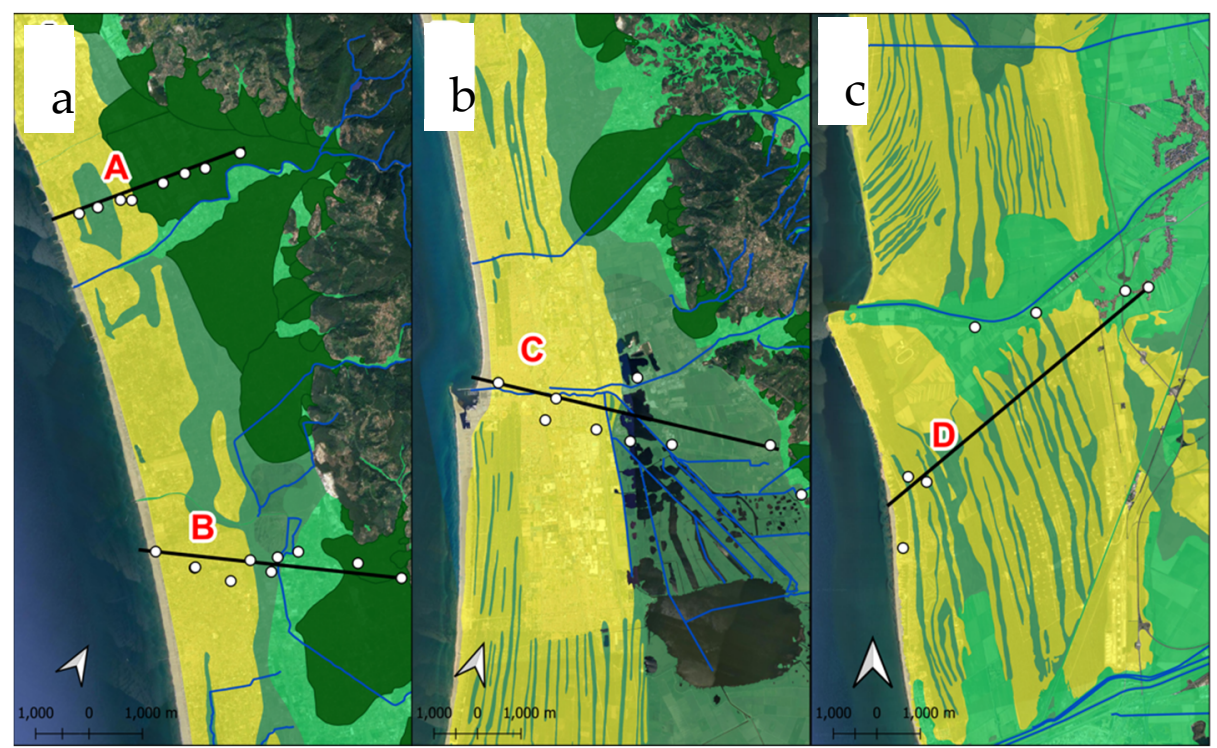

Figure 3. Location of the transects along which the four stratigraphic sections are produced. (a) Location of Sections A and B; (b) location of Section C; and (c) location of Section D. The white circles represent the locations of the boreholes used for the stratigraphic sections.

Four stratigraphic sections were produced to infer the subsurface stratigraphic architecture recorded during the Holocene (Figures 4 and 5). Each section shows the typical depositional wedge recording the retrogradational and progradational phases. Section A is about $7 \mathrm{~km}$ south of the Port of Marina di Carrara (Figures 3 and 4). It shows the Holocene wedge that overlies in unconformity a gravel substrate related to the Pleistocene alluvial fans. 


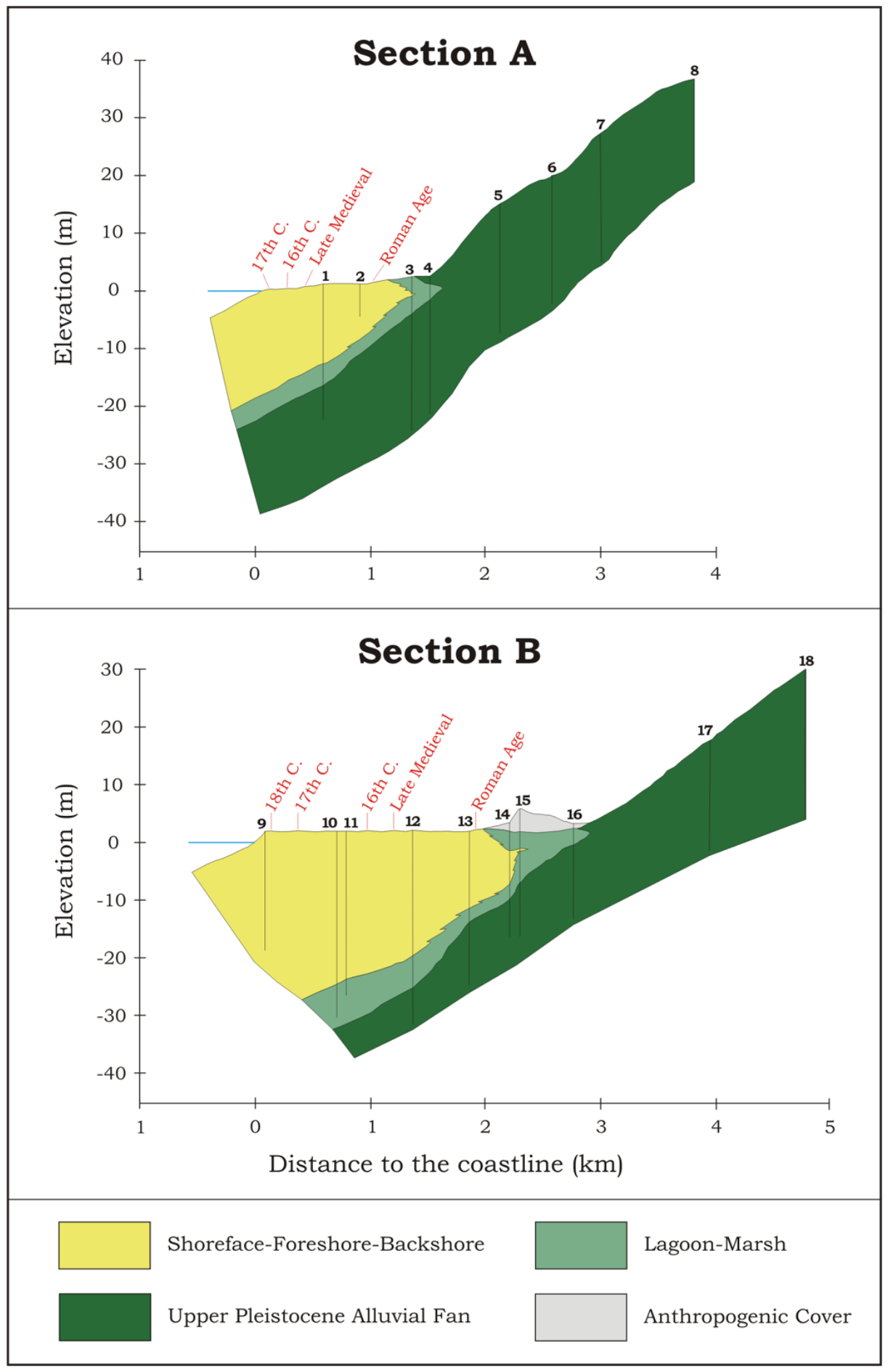

Figure 4. Stratigraphic sections A and B. The current position of the coastline is located at $0 \mathrm{~m}$ along the $\mathrm{x}$-axis. The numbers in black correspond to the boreholes used to produce the sections. The vertical scale is exaggerated by a factor of 20.1 : SIRA 54; 2 : SIRA 55; 3: DAPAT 125; 4: DM 85; 5: DC OLIV EMW 3a; 6: DC OLIV EMW 7; 7: DC PRAN S12 secondo; 8: DC PRAN S282; 9: SIRA 136; 10: SIRA 145; 11: DC PRAN S96; 12: DAPAT 112; 13: DM 108; 14: DC PRAN S122; 15: SIRA 170; 16: DPS S2; 17: DAPAT 198; 18: DAPAT 229. 


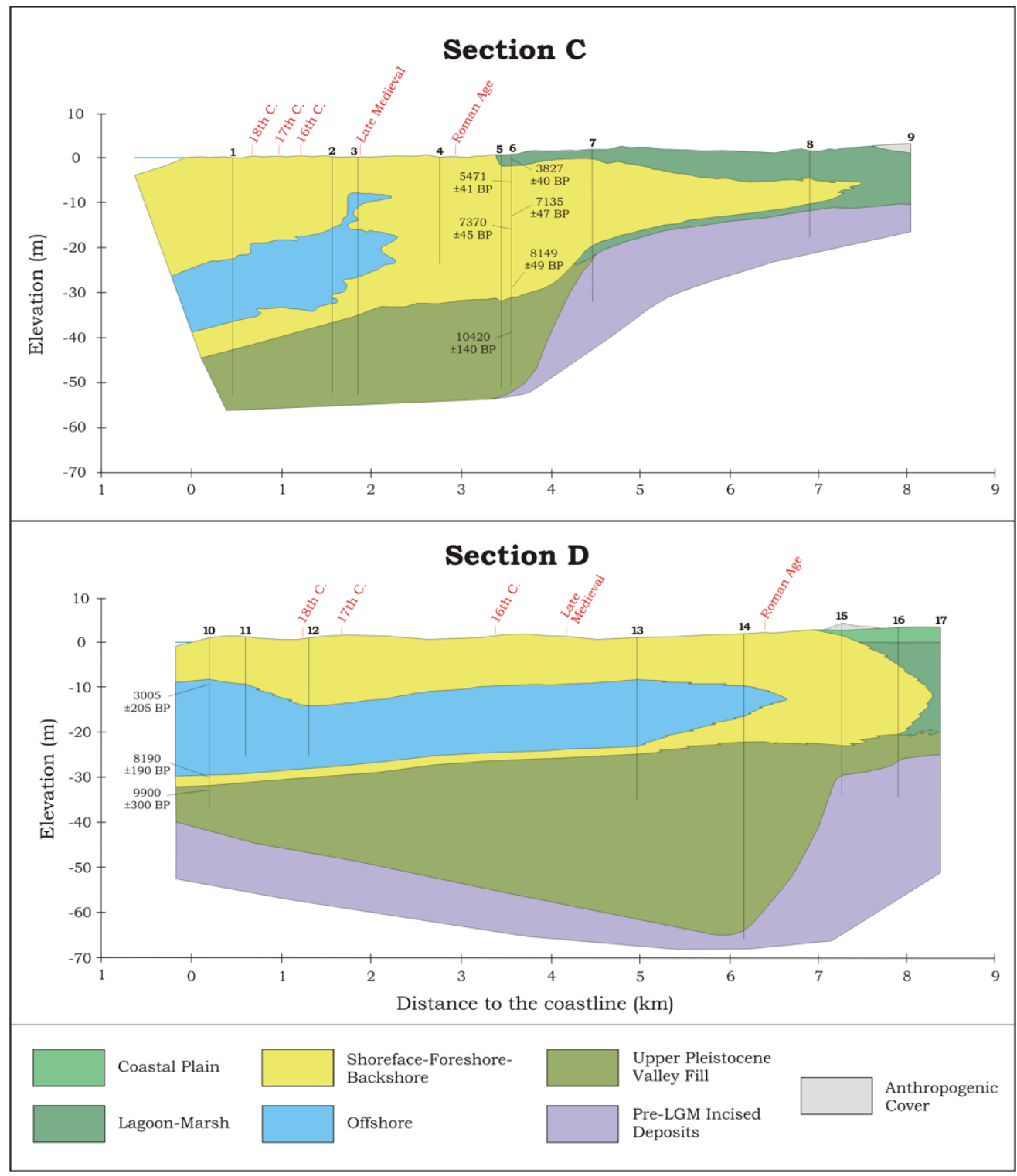

Figure 5. Stratigraphic sections $C$ and D. The current position of the coastline is located at $0 \mathrm{~m}$ along the $\mathrm{x}$-axis. The numbers in black correspond to the boreholes used to produce the sections. The vertical scale is exaggerated by a factor of 20. 1: SIRA 113; 2: DB ITALMACO; 3: SALOV; 4: CSN 151; 5: RECORD 47; 6: BERGAMIN; 7: SIRA 177; 8: SIRA 257; 9: RECORD 159; 10: M1; 11: RMS26; 12: C2806; 13: VIRGO 2; 14: BG; 15: DBS BASILICA; 16: C5976; 17: C5806.

The wedge thickness is about $22 \mathrm{~m}$ at the present coastline position and drops to zero about $1.5 \mathrm{~km}$ inland. The gravel deposits outcrop about $1.7 \mathrm{~km}$ inland from the present-day coastline, forming a slight slope $(1.5 \%)$. The base of the transgression is marked by lagoon deposits, passing upward to backshore and shoreface sands. The most-landward location of the coastline migration is located about $1.2 \mathrm{~km}$ inland from the present-day position. Section B is located about $6.5 \mathrm{~km}$ southwards (Figures 3 and 4 ). In this area, the thickness of the depositional wedge increases around $35 \mathrm{~m}$ at the location of the borehole SIRA 145. The substrate is still made of gravel related to the Pleistocene alluvial fan growth; it outcrops about $2.8 \mathrm{~km}$ inland from the coastline, which coincides with the landward wedge termination. Here the slope is less steep (1.4\%). The retrogradational deposits consist of lagoon to beach-related deposits, while the progradation cycle is represented by the development of a wide strandplain. The innermost point of coastline migration is slightly 
more than $2 \mathrm{~km}$ from the present-day position. Section $C$ is about $14 \mathrm{~km}$ southwards, just north of the Port of Viareggio (Figures 3 and 5).

This area was affected by strong erosional processes that took place during the Last Glacial Maximum (LMG) [29]; as a result, the retrogradational-progradational cycle that overlies the upper Pleistocene-Holocene valley-fill sequence (related to the paleo-Serchio River) is about $45 \mathrm{~m}$ thick. In this section, the landward coastline shift during the maximum marine transgression increased up to no less than $7 \mathrm{~km}$ (see SIRA 257 borehole in Figure 4), leading to the establishment of offshore depositional conditions up to about $2 \mathrm{~km}$ from the present-day coastline (see Italmaco and Salov boreholes in Figure 4). Landward of the marine depositional wedge, a wide marsh and lake area (the present-day Massaciuccoli Lake) developed. Section D is located just southward of the Arno River (Figures 3 and 5). Here the coastal plain area widens significantly. The substrate, represented by the Pisani Mounts, outcrops about $20 \mathrm{~km}$ from the present-day coastline. Similar to Section B, the retrogradational-progradational sandy wedge lies above a valley-fill sequence related to the paleo-Arno River. The most landward point of coastline migration shifted to no less than $8 \mathrm{~km}$ from the present-day position (see boreholes C5976 and C5806 in Figure 4), and large sectors of the present coastal plain were flooded by the sea during the retrogradational phase. The following phase of progradation resulted in the growth of a wide strandplain characterized by the juxtaposition of many beach ridges and by the development of a wide lagoon and marsh area, which reached the Pisani Mounts [28].

\subsection{Historical Evolution (Tens of Centuries of Years)}

The beach ridge system was formed by the juxtaposition of consecutive foredune alignments, which is a characteristic feature of the study area. The natural setting is preserved at just a few sites, though (e.g., the Migliarino-San Rossore-Massaciuccoli Regional Park), as anthropogenic pressure is responsible for the obliteration of vast sectors. The location of each foredune alignment approximately corresponds to the location of the coastline at the time of its formation. The innermost beach ridge outcrops are scattered along the study area. The age of this beach ridge in the area between Livorno and the Serchio River (Figure 2) can be deduced by historical sources. Based on the narrative of Strabo (V, 2, 5, C 222), the position of the coastline in the first century BC would fit with the west side of the innermost beach ridge [68]. This beach ridge leans on the distal portion of the alluvial fan lobes in the northernmost sector of the cell (Figure 2). During this phase, the coastline was located landward from the current position at an average of $6 \mathrm{~km}$ south of the Arno River, $5 \mathrm{~km}$ in the area between the Arno and Serchio rivers, and $4 \mathrm{~km}$ past the Serchio River up to the Port of Viareggio. The distance from the current position gradually decreases to about $1.5 \mathrm{~km}$ in the sector north of Viareggio. According to [34], several other beach ridge alignments were identified in the study area. They document an overall seaward progradation of the coastline. In this study, four beach ridges were highlighted after the Roman age (late medieval, 16th century, 17th century, and 18th century) in Figure 2. The transition from straight to arcuate and back to straight beach ridge alignments implied non-uniform progradation rates over time in the area of the Arno River mouth (Figure 2). Changes in the coastline progradation rate were also documented in the Versilia coastal plain [76].

\subsection{Current Situation (Tens of Years)}

Research by [70] analyzed the shoreline position in the sector between the Port of Viareggio and Livorno with historical maps and remote sensing analysis, identifying the time intervals and the areas subject to the most severe erosion effects since 1878. The peak coastline retreat was reached in the area north of the Arno River mouth in the 1938-1954 period (about $20 \mathrm{~m}$ per year). Research by [71] presented an assessment of coastal area spatial variation in the same sector during the last 140 years. They reported that more than $2.5 \mathrm{~km}^{2}$ of the area experienced constant erosion, whereas just $0.5 \mathrm{~km}^{2}$ showed constant accretion. However, these two papers studied only the southernmost sector of the littoral 
cell. Research by [45] extended the analysis along the whole cell, identifying the most critical situations in the areas south of the Magra River mouth and north of the Arno River mouth. A study by [42] confirmed these trends, focusing on five selected time intervals $(1938,1954,1978,1996$, and 2019).

\section{Discussion}

The analysis and the integration of available datasets belonging to different space-time scale frameworks prompted a more in-depth knowledge about the coastal evolution of the study area; they also provided an additional tool for better management of the coast.

\subsection{Geological and Geomorphological Legacy}

The evolution of the northern Tuscany littoral cell has been strongly influenced by geological and geomorphological factors, mainly raised after the Last Glacial Maximum (LGM). The Apennines chain borders the cell inland from the area of the Magra River to the Pisani Mounts. The Pleistocene-Holocene deposits of the Arno River plain developed south of the Pisani Mounts, which represent the northern edge of the plain. Within this framework, two main areas with different pre-Holocene geological and geomorphological legacies can be identified from north to south: (a) the area between the Magra River and Camaiore and (b) the area between Camaiore and the Scolmatore channel (Figure 2). During the LGM, the northernmost sector (a) was characterized by the development of prograding alluvial fans supplied by the Apennines. The frontal edge of the three main alluvial fan systems (Carrione, Frigido, and Versilia) worked as a small cliff or steep slope during the mid-to-late Holocene transgression, limiting landward flooding. Evidence of small cliffs, currently not outcropping, has been documented at the toe of the coalescent alluvial fan $[36,67,77,78]$. The integration of subsurface and morphological data for the studied sections (Figures 2 and 4) suggested a slope value between 1.5\% and 1.4\%. Sector (b) was characterized by multiple incised valleys [29], which were flooded during the early Holocene transgression with the development of estuarine depositional environments. Since about $7000 \mathrm{yr}$ BP, the marine transgression has drowned the levees of the LGM paleo-valleys [29], resulting in the flooding of large, almost flat interfluve areas (about $0.4 \%$; Figures 2 and 5).

\subsection{Sediment Supplies and Conveyor Belts}

The two main sediment conveyor belts along the northern Tuscany littoral cell are the Magra and Arno rivers. The Serchio River influence is subordinate, as it was a tributary of the Arno River for extended periods of time [79]. Regardless of the volume of sediment supplied over time, the Magra and Arno rivers showed marked hydrodynamic differences that have been (and still are) crucial for the evolution of the northern Tuscany littoral cell. The first difference regards their late Holocene evolution. The Arno River, as well as many other streams in the Mediterranean area [80-82], changed its mouth dynamics from a wave-dominated estuary to a wave-dominated delta ca. $3 \mathrm{Ky} \mathrm{BP}$, triggering the growth of wide strandplains. The transition from estuary to delta was caused by the drowning and filling of the LMG Arno and Serchio valleys [29,57]. The Magra River flows within the Magra Basin and is characterized by the presence of a submerged fan [41]. Both its final stretch and mouth are constrained by the Punta Bianca headland to the west and by the Apennines to the east (Figure 1). This peculiar geological setting - a river flowing in an intermountain valley so close to the sea-inhibits the development of a delta stage, which has favored the formation of the submerged fan with an apex located at the mouth of the river. The second difference is the orientation of river mouths relative to the coastline evolution. The Arno River flows approximately orthogonally to the coastline, enabling the strandplain to prograde in a seaward direction. The Magra River flows into the sea almost parallel to the coastline. The presence of the Punta Bianca headland to the northwest forces the river to distribute its bedload southwards, which is the reason why the coastal plain 
developed in the southern direction rather than to the north, resulting in the siltation of the mouth that occurred in the past [83].

\subsection{Natural vs. Anthropogenic Driving Factors}

According to the sequence stratigraphic model, eustasy, local tectonics, and sediment supply are the natural driving factors in the development of strandplain coasts over time [84]. The natural sea-level rise that globally characterized the upper Pleistocene and Holocene times [85-87] has experienced a strong increase due to the greenhouse effect lately [88-90]. For the Mediterranean area [91], the increase in sea-level rise between the pre- $(0.3 \pm 0.7 \mathrm{~mm}$ per year) and post-industrial eras $(0.55 \pm 0.6 \mathrm{~mm}$ per year $)(1850 \mathrm{CE})$ is now up to four times higher $(1.05 \pm 0.6 \mathrm{~mm}$ per year). Eustatic sea-level rise is enhanced by local tectonics, determining the relative sea-level rise. The study area is affected by a natural tectonic subsidence and sediment compaction $[33,59,74,92,93]$. The strong anthropization of the northern Tuscany littoral cell, except for the Migliarino-San Rossore-Massaciuccoli Regional Park, has established an over-exploitation of water resources, which hampers the complete recharge cycle of the aquifers. This has triggered processes of anthropogenic subsidence $[74,94]$ that add up to the natural subsidence. The other main factor is the sediment supply in terms of volume. Even though it is hardly quantifiable, the geological and historical data indicate that, up to the mid-19th century, the sediment supply was enough to foster a general seaward progradation of the system. Coastal erosion effects began to strike the littoral cell soon thereafter, reaching severe rates in the 20th century due to the intense human pressure that characterized many sectors of the study area. As a matter of fact, [42] introduced the concept of "anthropogenic sub-cells" to explain the modification of sediment distribution in specific sectors of the littoral cell. Recent data [95] point out that in the last 40 years the anthropogenic sedimentary budget has been negative for $243,900 \mathrm{~m}^{3}$ due to inland activities, such as river damming, mountain slope reforestation, and river-bed dredging. However, this value is negligible compared to the amount of sediment dredged from the Magra River between 1958-1973, which was reportedly about 24 million cubic meters [96]. Such a sediment deficit is responsible for the strong erosion processes that affect several sectors of the littoral cell.

\section{Conclusions}

The analysis and the integration of datasets related to different space-time scales underlined the strict relationships between the current situation of the northern Tuscany littoral cell and its historical and geological legacies. In the framework of global sea-level rise, the study area is located in a natural subsidence zone characterized by a positive relative sea-level rise, which is amplified by anthropogenic factors acting at different space-time scales (e.g., greenhouse effect, local anthropogenic subsidence, and sediment supply decrease). During the historical time, the creation of new accommodation space (sensu [97]) was overcome (positive balance) by a huge amount of sediment supplied by the rivers as a consequence of intense deforestation, resulting in a strong progradation characterized by the formation of wide strandplains. Since the industrial era, the increase of accommodation space and the drastic human-induced decrement of sediment supply has produced a negative balance; in stratigraphic sequence terms, this resulted in an initial phase of coastline retrogradation consisting of erosional processes. The erosional processes are more sensitive in the northern sector due to different LGM geological and geomorphological legacies: a narrow area constrained by the Apennines with a steep coast formed by alluvial fan bodies, as opposed to an almost flat and open area in the southern sector. Furthermore, the presence of two ports and the construction of many hard defense structures modified the patterns of the natural littoral drifts [42]. In summary, anthropogenic impact is currently the main factor driving the northern Tuscany littoral cell coastline evolution affected by strong erosional processes. Since the driving factors (natural and anthropogenic) discussed are common in world-wide urbanized strandplains, the northern Tuscany littoral cell can be considered as a case history. As a matter of 
fact, this aspect has been separately addressed in many recent morphodynamic [98-101], geomorphological [102-105], and geological [106-108] studies, but never with integration of the three perspectives. We believe that a multidisciplinary space-time approach constitutes a valuable method to improve the knowledge of the present-day coastal situation, providing a general framework useful to (a) elaborate more reliable coastal evolution scenarios and (b) acquire, from both a geological and historical perspective, analog models of coastline changes under natural and anthropogenic driving factors. To achieve conscious and responsible coastal management, we underline the need for continuous integration of each database. A complex, multidisciplinary approach is essential to address equally complex issues, such as coastal management, in a way similar to the conceptualization of the "Water Systems" proposed by [109] regarding society-nature relations. Reaching this goal requires accurate planning and cooperation among researchers, stakeholders, and public administrations to face the challenge over the next tens of years of finding sustainable solutions, not only for coastal erosion, but also for coastal flooding.

Author Contributions: Conceptualization, G.S.; methodology, G.S., D.B. and M.B.; software, D.B. and M.B.; validation, G.S.; investigation, G.S., D.B. and M.B.; writing-original draft preparation, G.S.; writing—review and editing, D.B.; visualization, D.B. and M.B.; supervision, G.S. All authors have read and agreed to the published version of the manuscript.

Funding: This research received no external funding.

Institutional Review Board Statement: Not applicable.

Informed Consent Statement: Not applicable.

Data Availability Statement: Publicly available datasets were analyzed in this study. This data can be found here: http:/ / www.mappaproject.org/?lang=en; https://www.regione.toscana.it/-/geoscopio; https://opendata.provincia.pisa.it.

Acknowledgments: We are thankful to Roberto Mattei for his detailed review of existing boreholes and the ensuing database. Suggestions raised by two anonymous reviewers led to improvements in the manuscript. This manuscript is part of the activities of the "Team COSTE" research group.

Conflicts of Interest: The authors declare no conflict of interest.

\section{References}

1. Ramieri, E.; Hartley, A.; Barbanti, A.; Duarte Santos, F.; Gomes, A.; Hilden, M.; Laihonen, P.; Marinova, N.; Santini, M. Methods for assessing coastal vulnerability to climate change. In ETC CCA Technical Paper 1/2011; ETC/CCA: Bologna, Italy, 2011; Volume 1, pp. 1-93.

2. Engelbert, A.; Collet, I. Coastal regions: People living along the coastline and integration of NUTS 2010 and latest population grid. Eurostat Stat. Focus 2013, 30, 1-12.

3. McMichael, C.; Dasgupta, S.; Ayeb-Karlsson, S.; Kelman, I. A review of estimating population exposure to sea-level rise and the relevance for migration. Environ. Res. Lett. 2020, 15, 123005. [CrossRef] [PubMed]

4. Census Bureau Website. Available online: https://www.census.gov/topics/preparedness/about/coastal-areas.html (accessed on 7 February 2022).

5. Maul, G.A.; Duedall, I.W. Demography of coastal population. In Encyclopedia of Coastal Science, 2nd ed.; Finkl, C.W., Makowski, C., Eds.; Springer: Cham, Switzerland, 2019; pp. 692-700.

6. Burke, L.; Kura, Y.; Kassem, K.; Revenga, C.; Spalding, M.; McAllister, D. Coastal Ecosystems; World Resources Institute: Washington, DC, USA, 2001; p. 77.

7. Frihy, O.E.; El-Sayed, M.K. Vulnerability risk assessment and adaptation to climate change induced sea level rise along the Mediterranean coast of Egypt. Mitig. Adapt. Strateg. Glob. Change 2013, 18, 1215-1237. [CrossRef]

8. Aiello, A.; Canora, F.; Pasquariello, G.; Spilotro, G. Shoreline variations and coastal dynamics: A space-time data analysis of the Jonian littoral, Italy. Estuar. Coast. Shelf Sic. 2013, 129, 124-135. [CrossRef]

9. Brahim, M.; Abdelfattah, A.; Sammari, C.; Aleya, L. Surface sediment dynamics along with hydrodynamics along the shores of Tunis Gulf (north-eastern Mediterranean). J. Afr. Earth Sci. 2015, 103, 30-41. [CrossRef]

10. Jiménez, J.A.; Valdemoro, H.I.; Bosom, E.; Sánchez-Arcilla, A.; Nicholls, R.J. Impacts of sea-level rise-induced erosion on the Catalan coast. Reg. Environ. Change 2017, 17, 593-603. [CrossRef]

11. Martínez, M.L.; Landgrave, R.; Silva, R.; Hesp, P. Shoreline dynamics and coastal dune stabilization in response to changes in infrastructure and climate. J. Coastal Res. 2019, SI92, 6-12. [CrossRef] 
12. Kelly, J.T.; McSweeney, S.; Shulmeister, J.; Gontz, A.M. Bimodal climate control of shoreline change influenced by Interdecadal Pacific Oscillation variability along the Cooloola Sand Mass, Queensland, Australia. Mar. Geol. 2019, 415, 105971. [CrossRef]

13. Chu, L.; Oloo, F.; Sudmanns, M.; Tiede, D.; Hölbling, D.; Blaschke, T.; Teleoaca, I. Monitoring long-term shoreline dynamics and human activities in the Hangzhou Bay, China, combining daytime and nighttime EO data. Big Earth Data 2020, 4, $242-264$. [CrossRef]

14. Awad, M.; El-Sayed, H.M. The analysis of shoreline change dynamics and future predictions using automated spatial techniques: Case of El-Omayed on the Mediterranean coast of Egypt. Ocean Coast. Manag. 2021, 205, 105568. [CrossRef]

15. Athanasiou, P.; van Dongeren, A.; Giardino, A.; Vousdoukas, M.I.; Ranasinghe, R.; Kwadijk, J. Uncertainties in projections of sandy beach erosion due to sea level rise: An analysis at the European scale. Sci. Rep. 2020, 10, 11895. [CrossRef]

16. Shirzaei, M.; Freymueller, J.; Törnqvist, T.E.; Galloway, D.L.; Dura, T.; Minderhoud, P.S. Measuring, modelling and projecting coastal land subsidence. Nature Rev. Earth Environ. 2021, 2, 40-58. [CrossRef]

17. Deelstra, T. Impact of Climatic Change on Coastal Cities. In Climate Change_Impact on Coastal Habitation, 1st ed.; Eisma, D., Ed.; CRC Press: Boca Raton, FL, USA, 1995; pp. 163-188.

18. Cazenave, A.; Cozannet, G.L. Sea level rise and its coastal impacts. Earth's Future 2014, 2, 15-34. [CrossRef]

19. Slangen, A.B.; Meyssignac, B.; Agosta, C.; Champollion, N.; Church, J.A.; Fettweis, X.; Ligtenberg, S.R.M.; Marzeion, B.; Melet, A.; Palmer, M.D.; et al. Evaluating model simulations of twentieth-century sea level rise. Part I: Global mean sea level change. J. Climate 2017, 30, 8539-8563. [CrossRef]

20. Taramelli, A.; Manzo, C.; Valentini, E.; Cornacchia, L. Coastal Subsidence: Causes, Mapping and Monitoring. In Natural Hazards-Earthquakes, Volcanoes, and Landslides, 1st ed.; Singh, R., Bartlett, D., Eds.; CRC Press: Boca Raton, FL, USA, 2018; pp. 253-290.

21. Wolff, C.; Nikoletopoulos, T.; Hinkel, J.; Vafeidis, A.T. Future urban development exacerbates coastal exposure in the Mediterranean. Sci. Rep. 2020, 10, 14420. [CrossRef]

22. Calabrese, L.; Luciani, P.; Perini, L. A review of impact of subsidence induced by gas exploitation on costal erosion in EmiliaRomagna, Italy. Boll. Geofis. Teor. Appl. 2021, 62, 279-300.

23. Malinverno, A.; Ryan, W.B.F. Extension in the Tyrrhenian Sea and shortening in the Apennines as result of arc migration driven by sinking of the lithosphere. Tectonics 1986, 5, 227-245. [CrossRef]

24. Mariani, M.; Prato, R. I bacini neogenici costieri del margine tirrenico: Approccio sismico-stratigrafico. Mem. Soc. Geol. Italy 1988, 41, 519-531.

25. Antonioli, F.; Ferranti, L.; Fontana, A.; Amorosi, A.; Bondesan, A.; Braitenberg, C.; Dutton, A.; Fontolan, G.; Furlani, S.; Lambeck, K.; et al. Holocene relative sea-level changes and vertical movements along the Italian and Istrian coastlines. Quatern. Int. 2009, 206, 102-133. [CrossRef]

26. Molli, G.; Manighetti, I.; Bennett, R.; Malavieille, J.; Serpelloni, E.; Storti, F.; Giampietro, T.; Bigot, A.; Pinelli, G.; Giacomelli, S.; et al. Active Fault Systems in the Inner Northwest Apennines, Italy: A Reappraisal One Century after the 1920 Mw 6.5 Fivizzano Earthquake. Geosciences 2021, 11, 139. [CrossRef]

27. Bartole, R.; Torelli, L.; Mattei, G.; Peis, D.; Brancolini, G. Assetto stratigrafico del Tirreno Settentrionale: Stato dell'arte. Studi Geol. Camerti 1991, 1, 115-140.

28. Aguzzi, M.; Amorosi, A.; Colalongo, M.L.; Lucchi, M.R.; Rossi, V.; Sarti, G.; Vaiani, S.C. Late Quaternary climatic evolution of the Arno coastal plain (Western Tuscany, Italy) from subsurface data. Sediment. Geol. 2007, 202, 211-229. [CrossRef]

29. Amorosi, A.; Rossi, V.; Sarti, G.; Mattei, R. Coalescent valley fills from the late Quaternary record of Tuscany (Italy). Quatern. Int. 2013, 288, 129-138. [CrossRef]

30. Sarti, G.; Rossi, V.; Amorosi, A.; Bini, M.; Giacomelli, S.; Pappalardo, M.; Ribecai, C.; Ribolini, A.; Sammartino, I. Climatic signature of two mid-late Holocene fluvial incisions formed under sea-level highstand conditions (Pisa coastal plain, NW Tuscany, Italy). Palaeogeogr. Palaeocl. 2015, 424, 183-195. [CrossRef]

31. Federici, P.R.; Raggi, G. Una nuova interpretazione della tettonica dei monti della Spezia. B. Soc. Geol. Italy 1975, $94,945-960$.

32. Storti, F. Tectonics of the Punta Bianca promontory: Insights for the evolution of the Northern Apennines-Northern Tyrrhenian Sea basin. Tectonics 1995, 14, 832-847. [CrossRef]

33. Pascucci, V. Neogene evolution of the Viareggio basin, northern Tuscany (Italy). GeoActa 2005, 4, 123-138.

34. Bertoni, D.; Giacomelli, S.; Ciulli, L.; Sarti, G. Litho-sedimentological and morphodynamic characterization of the Pisa Province coastal area (northern Tuscany, Italy). J. Maps 2020, 16, 108-116. [CrossRef]

35. Alquini, F.; Bertoni, D.; Sarti, G. Extreme erosion of a dune crest within a short timespan (January-September 2016): The recent case in the Migliarino-San Rossore-Massaciuccoli Regional Park (Tuscany, Italy). Atti Soc. Toscana Sci. Nat. Mem. Ser. A 2016, 123, 5-16.

36. Mazzanti, R.; Pasquinucci, M. L'evoluzione del litorale lunense-pisano fino alla metà del XIX secolo. Boll. Soc. Geogr. Italy 1983, 12, 605-628.

37. Ceccarelli Lemut, M.L.; Mazzanti, R.; Morelli, P. Il contributo delle fonti storiche alla conoscenza della geomorfologia. In La Pianura di Pisa e i Rilievi Contermini; Mazzanti, R., Ed.; Società Geografica Italiana: Roma, Italy, 1994; pp. 401-429.

38. Fabiani, F. “ . . Stratam Antiquam que est per Paludes et Boscos ... ". Viabilità Romana tra Pisa e Luni; Edizioni Plus: Pisa, Italy, 2006; p. 191. 
39. Piccardi, M.; Pranzini, E. Le foci del Serchio e del Fiume Morto nelle restituzioni cartografiche pre-geodetiche. Studi Costieri 2016, 23, 21-58.

40. Bini, M.; Baroni, C.; Ribolini, A. Geoarchaeology as a tool for reconstructing the evolution of the Apuo-Versilian Plain (NW Italy). Geogr. Fis. Din. Quat. 2013, 36, 215-224.

41. Conti, P.; Carmignani, L.; Massa, G.; Meccheri, M.; Fantozzi, P.L.; Masetti, G.; Rossetto, R. Note Illustrative della Carta Geologica d'Italia alla Scala 1:50.000 "Foglio 260_Viareggio"; Servizio Geologico d'Italia: Roma, Italy, 2012; p. 145.

42. Bertoni, D.; Bini, M.; Luppichini, M.; Cipriani, L.E.; Carli, A.; Sarti, G. Anthropogenic Impact on Beach Heterogeneity within a Littoral Cell (Northern Tuscany, Italy). J. Mar. Sci. Eng. 2021, 9, 151. [CrossRef]

43. Pranzini, E. Updrift river mouth migration on cuspate deltas: Two examples from the coast of Tuscany (Italy). Geomorphology 2001, 38, 125-132. [CrossRef]

44. Cipriani, L.E.; Ferri, S.; Iannotta, P.; Paolieri, F.; Pranzini, E. Morfologia e dinamica dei sedimenti del litorale della Toscana settentrionale. Studi Costieri 2001, 4, 119-156.

45. Cipriani, L.E.; Pranzini, E.; Vitale, G. Coastal erosion in Tuscany: Short vs. medium term evolution. In Coastal Erosion Monitoring. A Network of Regional Observatories—Results from RESMAR Project; Cipriani, L.E., Ed.; Nuova Grafica Fiorentina: Florence, Italy, 2013; pp. 135-155.

46. Gandolfi, G.; Paganelli, L. Il litorale pisano-versiliese (Area campione Alto Tirreno). Composizione, provenienza e dispersione delle sabbie. Boll. Soc. Geol. Italy 1975, 94, 1273-1295.

47. Garzanti, E.; Canclini, S.; Moretti Foggia, F.; Petrella, N. Unraveling magmatic and orogenic provenance in modern sand: The back-arc side of the Apennine thrust belt, Italy. J. Sediment. Res. 2002, 72, 2-17. [CrossRef]

48. Bertoni, D.; Biagioni, C.; Sarti, G.; Ciccarelli, D.; Ruocco, M. The role of sediment grain-size, mineralogy, and beach morphology on plant communities of two Mediterranean coastal dune systems. Italy J. Geosci. 2014, 133, 271-281. [CrossRef]

49. Sarti, G.; Bertoni, D. Monitoring backshore and foreshore gravel deposits on a mixed sand and gravel beach (Apuane-Versilia coast, Tuscany, Italy). GeoActa 2007, 6, 73-81.

50. Bertoni, D.; Sarti, G. Grain size characterization of modern and ancient dunes within a dune field along the Pisan coast (Tuscany, Italy). Atti Soc. Toscana Sci. Nat. Mem. Ser. A 2011, 116, 11-16.

51. Nordstrom, K.F.; Pranzini, E.; Jackson, N.L.; Coli, M. The marble beaches of Tuscany. Geogr. Rev. 2008, 98, 280-300. [CrossRef]

52. Bertoni, D.; Sarti, G.; Benelli, G.; Pozzebon, A. In situ abrasion of marked pebbles on two coarse-clastic beaches (Marina di Pisa, Italy). Italy J. Geosci. 2012, 131, 205-214.

53. Mappa Project Website. Available online: http://www.mappaproject.org/?lang=en (accessed on 8 February 2022).

54. GEOscopio Website. Available online: https://www.regione.toscana.it/-/geoscopio (accessed on 8 February 2022).

55. Provincia di Pisa Open Data Website. Available online: https://opendata.provincia.pisa.it (accessed on 8 February 2022).

56. Bergamin, L.; Di Bella, L.; Frezza, V.; Devoti, S.; Nisi, M.F.; Silenzi, S.; Carboni, M.G. Late Quaternary palaeoenvironmental evolution at the Versilian coast (Tuscany, Italy): Micropalaentological proxies. In Proceedings of the Second and Third Italian Meetings on Environmental Micropaleontology, Urbino, Italy, 10-12 June 2003 and 8-9 June 2004; Special Publications 11. Coccioni, R., Marsili, A., Eds.; Grzybowski Foundation: Krakow, Poland, 2006; pp. 1-11.

57. Amorosi, A.; Ricci Lucchi, M.; Rossi, V.; Sarti, G. Climate change signature of small-scale parasequences from Lateglacial-Holocene transgressive deposits of the Arno valley fill. Palaeogeogr. Palaeocl. 2009, 273, 142-152. [CrossRef]

58. Carboni, M.G.; Bergamin, L.; Di Bella, L.; Esu, D.; Cerone, E.P.; Antonioli, F.; Verrubbi, V. Palaeoenvironmental reconstruction of late Quaternary foraminifera and molluscs from the ENEA borehole (Versilian plain, Tuscany, Italy). Quat. Res. 2010, 74, 265-276. [CrossRef]

59. Sarti, G.; Rossi, V.; Amorosi, A. Influence of Holocene stratigraphic architecture on ground surface settlements: A case study from the City of Pisa (Tuscany, Italy). Sediment. Geol. 2012, 281, 75-87. [CrossRef]

60. Rossi, V.; Amorosi, A.; Sarti, G.; Mariotti, S. Late Quaternary multiple incised valley systems: An unusually well-preserved stratigraphic record of two interglacial valley-fill successions from the Arno Plain (northern Tuscany, Italy). Sedimentology 2017, 64, 1901-1928. [CrossRef]

61. Amorosi, A.; Bini, M.; Fabiani, F.; Giacomelli, S.; Pappalardo, M.; Ribecai, C.; Ribolini, A.; Rossi, V.; Sammartino, I.; Sarti, G. MAPPA cores: An interdisciplinary approach. MapPapers 2012, 4en-II, 149-200.

62. Smith, C.D. Changing Environment and Roman Landscape: The ager Lunensis. In Luni and the Ager Lunensis-The Rise and Fall of a Roman Town and Its Territory; Smith, C.D., Gadd, D., Mills, N., Ward-Perkins, B., Eds.; Papers British School at Rome 1986, Volume 54; Cambridge University Press: New York, NY, USA; pp. 123-140.

63. Della Rocca, B.; Mazzanti, R.; Pranzini, E. Studio geomorfologico della pianura di Pisa. Geogr. Fis. Din. Quat. 1987, 10, 56-84.

64. Raggi, G.; Sansoni, G. Variazioni storiche e tendenza evolutiva della linea di riva lunense. Mem. Accad. Lunigianese Sci. 1993, 62-63, 3-43.

65. Mazzanti, R.; Nencini, C. La morfologia. In La Pianura di Pisa e i Rilievi Contermini; Mazzanti, R., Ed.; Società Geografica Italiana: Roma, Italy, 1994; pp. 89-102.

66. Dall'Antonia, B.; Mazzanti, R. Geomorfologia e Idrografia. In Tombolo. Territorio della Basilica di San Piero a Grado; Paglialunga, S., Ed.; Felici: Pisa, Italy, 2001; pp. 28-36.

67. Bini, M.; Chelli, A.; Pappalardo, M. Caratterizzazione geomorfologica della Piana Lunense nell'ottica di una ricostruzione del paesaggio costiero in età romana. Atti Soc. Toscana Sci. Nat. Mem. Ser. A 2006, 111, 57-66. 
68. Sarti, G.; Bini, M.; Giacomelli, S. The growth and decline of Pisa (Tuscany, Italy) up to the Middle Ages: Correlations with landscape and geology. Alp. Mediterr. Quat. 2010, 23, 311-322.

69. Amorosi, A.; Bini, M.; Giacomelli, S.; Pappalardo, M.; Ribecai, C.; Rossi, V.; Sammartino, I.; Sarti, G. Middle to late Holocene environmental evolution of the Pisa coastal plain (Tuscany, Italy) and early human settlements. Quatern. Int. 2013, 303, 93-106. [CrossRef]

70. Bini, M.; Casarosa, N.; Ribolini, A. Multitemporal (1938-2004) evolution of the Pisan shoreline based on the comparison of georeferenced aerial images. Atti Soc. Toscana Sci. Nat. Mem. Ser. A 2008, 113, 1-12.

71. Bini, M.; Casarosa, N.; Luppichini, M. Exploring the relationship between river discharge and coastal erosion: An integrated approach applied to the Pisa coastal plain (Italy). Remote Sens. 2021, 13, 226. [CrossRef]

72. Mazzanti, R.; Paribeni, E.; Storti, S.; Vaggioli, M.A. La pianura versiliese nel contesto geomorfologico. In Etruscorum Ante Quam Ligurum: La Versilia tra VII e III Secolo a.C.; Paribeni, E., Ed.; Bandecchi \& Vivaldi: Pontedera, Italy, 1990; pp. $33-43$.

73. Federici, P.R.; Mazzanti, R. Notes on the coastal plains of Tuscany. Mem. Soc. Geogr. Italy 1995, 53, 165-270.

74. Pranzini, E. Airborne LIDAR survey applied to the analysis of the historical evolution of the Arno River delta (Italy). J. Coast. Res. 2007, 50, 400-409.

75. Baroni, C.; Pieruccini, P.; Bini, M.; Coltorti, M.; Fantozzi, P.L.; Guidobaldi, G.; Nannini, D.; Ribolini, A.; Salvatore, M.C Geomorphological and neotectonic map of the Apuan Alps (Tuscany, Italy). Geogr. Fis. Din. Quat. 2015, 38, $201-227$.

76. Bini, M.; Sarti, G.; Da Prato, S.; Fabiani, F.; Paribeni, M.; Baroni, C. Geoarcheological evidences of changes in the coastline progradation rate of the versilia coastal plain between Camaiore and Viareggio (Tuscany, Italy): Possible relationships with Late Holocene high-frequency transgressive regressive cycles. Il Quaternario 2009, 22, 257-266.

77. Sestini, A. Un'antica ripa marina nella pianura costiera apuana. Atti Soc. Toscana Sci. Nat. Mem. Ser. A 1957, 57, 1-6.

78. Federici, P.R. The Versilian transgression of the Versilia area (Tuscany, Italy) in the light of drillings and radiometric data. Mem. Soc. Geogr. Italy 1993, 49, 217-225.

79. Bini, M.; Rossi, V.; Amorosi, A.; Pappalardo, M.; Sarti, G.; Noti, V.; Capitani, M.; Fabiani, F.; Gualandi, M.L. Palaeoenvironments and palaeotopography of a multilayered city during the Etruscan and Roman periods: Early interaction of fluvial processes and urban growth at Pisa (Tuscany, Italy). J. Archaeol. Sci. 2015, 59, 197-210. [CrossRef]

80. Amorosi, A.; Milli, S. Late Quaternary depositional architecture of Po and Tevere river deltas (Italy) and worldwide comparison with coeval deltaic successions. Sediment. Geol. 2001, 144, 357-375. [CrossRef]

81. Anthony, E.J.; Marriner, N.; Morhange, C. Human influence and the changing geomorphology of Mediterranean deltas and coasts over the last 6000 years: From progradation to destruction phase? Earth-Sci. Rev. 2014, 139, 336-361. [CrossRef]

82. Anthony, E.J. Sand and gravel supply from rivers to coasts: A review from a Mediterranean perspective. Atti Soc. Toscana Sci. Nat. Mem. Ser. A 2018, 125, 13-33.

83. Pratellesi, M.; Ciavola, P.; Ivaldi, R.; Anthony, E.J.; Armaroli, C. River-mouth geomorphological changes over $>130$ years (1882-2014) in a small Mediterranean delta: Is the Magra delta reverting to an estuary? Mar. Geol. 2018, 403, 215-224. [CrossRef]

84. Catuneanu, O. Sequence stratigraphy: Guidelines for a standard methodology. In Advances in Sequence Stratigraphy, 1st ed.; Montenari, M., Ed.; Academic Press: Cambridge, MA, USA, 2017; pp. 1-57.

85. Engelhart, S.E.; Horton, B.P. Holocene sea level database for the Atlantic coast of the United States. Quat. Sci. Rev. 2012, 54, 12-25. [CrossRef]

86. García-Artola, A.; Stéphan, P.; Cearreta, A.; Kopp, R.E.; Khan, N.S.; Horton, B.P. Holocene sea-level database from the Atlantic coast of Europe. Quat. Sci. Rev. 2018, 196, 177-192. [CrossRef]

87. Vacchi, M.; Marriner, N.; Morhange, C.; Spada, G.; Fontana, A.; Rovere, A. Multiproxy assessment of Holocene relative sea-level changes in the western Mediterranean: Sea-level variability and improvements in the definition of the isostatic signal. Earth-Sci. Rev. 2016, 155, 172-197. [CrossRef]

88. Bird, E.C. Present and future sea level: The effects of predicted global changes. In Climate Change-Impact on Coastal Habitation, 1st ed.; Eisma, D., Ed.; CRC Press: Boca Raton, FL, USA, 1995; pp. 29-56.

89. Cronin, T.M. Rapid sea-level rise. Quat. Sci. Rev. 2012, 56, 11-30. [CrossRef]

90. Church, J.A.; Clark, P.U.; Cazenave, A.; Gregory, J.M.; Jevrejeva, S.; Levermann, A.; Merrifield, M.A.; Milne, G.A.; Nerem, R.S.; Nunn, P.D.; et al. Sea Level Change. In Climate Change 2013: The Physical Science Basis. Contribution of Working Group I to the Fifth Assessment Report of the Intergovernmental Panel on Climate Change; Stocker, T.F., Qin, D., Plattner, G.K., Tignor, M., Allen, S.K., Boschung, J., Nauels, A., Xia, Y., Bex, V., Midgley, P.M., Eds.; Cambridge University Press: Cambridge, UK; New York, NY, USA, 2013; pp. 1137-1216.

91. Vacchi, M.; Joyse, K.M.; Kopp, R.E.; Marriner, N.; Kaniewski, D.; Rovere, A. Climate pacing of millennial sea-level change variability in the central and western Mediterranean. Nat. Commun. 2021, 12, 4013. [CrossRef]

92. Rossi, V.; Amorosi, A.; Sarti, G.; Potenza, M. Influence of inherited topography on the Holocene sedimentary evolution of coastal systems: An example from Arno coastal plain (Tuscany, Italy). Geomorphology 2011, 135, 117-128. [CrossRef]

93. Chelli, A.; Pappalardo, M.; Bini, M.; Brückner, H.; Neri, G.; Neri, M.; Spada, G. Assessing tectonic subsidence from estimates of Holocene relative sea-level change: An example from the NW Mediterranean (Magra Plain, Italy). Holocene 2017, 27, 1988-1999. [CrossRef]

94. Annuario ISPRAmbiente Website. Available online: https://annuario.isprambiente.it/sys_ind/78 (accessed on 9 February 2022). 
95. Cappucci, S.; Bertoni, D.; Cipriani, L.E.; Boninsegni, G.; Sarti, G. Assessment of the anthropogenic sediment budget of a littoral cell system (Northern Tuscany, Italy). Water 2020, 12, 3240. [CrossRef]

96. Rinaldi, M.; Simoncini, C.; Piégay, H. Scientific design strategy for promoting sustainable sediment management: The case of the Magra River (Central-Northern Italy). River Res. Appl. 2009, 25, 607-625. [CrossRef]

97. Posamentier, H.M.; Jervey, M.T.; Vail, P.R. Eustatic Controls on Clastics Deposition I-Conceptual Framework. In Sea Level Changes: An Integrated Approach; Special Publication No. 42; Wilgus, C.K., Hastings, B.S., Kendall, C.G.S.C., Posamentier, H.W., Ross, C.A., Van Wagoner, J.C., Eds.; Society of Economic Paleontologists and Mineralogists: Broken Arrow, OK, USA, 1988 ; pp. $109-124$.

98. Deng, J.; Harff, J.; Zhang, W.; Schneider, R.; Dudzińska-Nowak, J.; Giza, A.; Terefenko, P.; Furmańczyk, K. The dynamic equilibrium shore model for the reconstruction and future projection of coastal morphodynamics. In Coastline Changes of the Baltic Sea from South to East; Harff, J., Furmańczyk, K., von Storch, H., Eds.; Springer: Cham, Switzerland, 2017; pp. 87-106.

99. Eichentopf, S.; Karunarathna, H.; Alsina, J.M. Morphodynamics of sandy beaches under the influence of storm sequences: Current research status and future needs. Water Sci. Eng. 2019, 12, 221-234. [CrossRef]

100. Ozkan, C.; Perez, K.; Mayo, T. The impacts of wave energy conversion on coastal morphodynamics. Sci. Total Environ. 2020, 712, 136424. [CrossRef] [PubMed]

101. Zăinescu, F.; Anthony, E.; Vespremeanu-Stroe, A. River Jets Versus Wave-Driven Longshore Currents at River Mouths. Front. Mar. Sci. 2021, 8, 708258. [CrossRef]

102. Fitton, J.M.; Hansom, J.D.; Rennie, A.F. A national coastal erosion susceptibility model for Scotland. Ocean Coast. Manag. 2016, 132, 80-89. [CrossRef]

103. Mentaschi, L.; Vousdoukas, M.I.; Pekel, J.F.; Voukouvalas, E.; Feyen, L. Global long-term observations of coastal erosion and accretion. Sci. Rep. 2018, 8, 12876. [CrossRef]

104. Rangel-Buitrago, N.; Neal, W.J.; de Jonge, V.N. Risk assessment as tool for coastal erosion management. Ocean Coast. Manag. 2020, 186, 105099. [CrossRef]

105. Bitencourt, V.J.B.; Dillenburg, S.R.; Manzolli, R.P.; Barboza, E.G. Control factors in the evolution of Holocene coastal barriers in Southern Brazil. Geomorphology 2020, 360, 107180. [CrossRef]

106. Barboza, E.G.; Rosa, M.L.C.; Dillenburg, S.R.; Watanabe, D.S.; Esteves, T.; Martins, E.M.; Gruber, N.L. Diachronic condition between maximum transgressive and maximum eustatic sea-level in Holocene: Subsidies for coastal management. J. Coast. Res. 2018, 85, 446-450. [CrossRef]

107. Amorosi, A.; Barbieri, G.; Bruno, L.; Campo, B.; Drexler, T.M.; Hong, W.; Rossi, V.; Sammartino, I.; Scarponi, D.; Vaiani, S.C.; et al. Three-fold nature of coastal progradation during the Holocene eustatic highstand, Po Plain, Italy-close correspondence of stratal character with distribution patterns. Sedimentology 2019, 66, 3029-3052. [CrossRef]

108. Salomon, F.; Vittori, C.; Noirot, B.; Pleuger, E.; Rosa, C.; Mazzini, I.; Carbonel, P.; Djerbi, H.; Bellotti, P.; Goiran, J.P. Reconstruction of the Tiber Deltaic stratigraphic successions near Ostia using the PADM chart and tracking of the bedload-derived facies (Rome, Italy). Geomorphology 2020, 365, 107227. [CrossRef]

109. Tvedt, T. 'Water Systems', Environmental History and the Deconstruction of Nature. Environ. Hist. 2010, 16, 143-166. [CrossRef] 